\title{
Communication
}

[Comunicação]

\section{Diagnosis of Brucella ovis infection by serology and PCR in urine samples from naturally infected rams in the State of Piauí}

[Diagnóstico da infecção por Brucella ovis por sorologia e reação em cadeia pela polimerase (PCR) em amostras de urina de carneiros naturalmente infectados no Estado do Piauí]

\author{
E.A. Costa ${ }^{1}$, F.M. Sant'Ana ${ }^{1}$, C.J.S. Carvalho ${ }^{2}$, V.S. Moustacas ${ }^{1}$, S.M.M.S. Silva ${ }^{1,2}$, \\ T.A. Paixã $o^{3}$, R.L. Santos ${ }^{1 *}$ \\ ${ }^{1}$ Escola de Veterinária - Universidade Federal de Minas Gerais - Belo Horizonte, MG \\ ${ }^{2}$ Universidade Federal do Piauí - Teresina, PI \\ ${ }^{3}$ Instituto de Ciências Biológicas - Universidade Federal de Minas Gerais - Belo Horizonte, MG
}

Ovine brucellosis caused by Brucella ovis is a disease with worldwide distribution. B. ovis is a facultative intracellular Gram-negative coccobacillus belonging to the genus Brucella (Xavier et al., 2009). The infection in sheep may be often asymptomatic, but it is usually characterized by epididymitis and orchitis in rams, and occasionally abortion in ewes, and neonatal mortality. Therefore, B. ovis infection ultimately leads to infertility, early culling, and consequently economic losses (Burgess, 1982). Prevalence of infection is highly variable among different regions in the world, ranging from 2.4 to $46.7 \%$ of infected animals and 2.1 to $67 \%$ of soropositive flocks (Robles et al., 1993, Sergeant, 1994). In Brazil, prevalence data is fragmented, with reports of $13.7 \%$ in the State of Rio Grande do Sul (Magalhães Neto and GilTurnes, 1996), 8.6\% in Paraíba (Clementino et al., 2007), 17.5\% in Pernambuco (Coleto et al., 2003), 12\% in São Paulo (Nozaki et al., 2004), and $11.3 \%$ in Rio Grande do Norte (Azevedo et $a l ., 2004)$. There are no previous reports of $B$. ovis infection in the State of Piauí.

Traditionally, diagnosis of $B$. ovis infection is based on clinical examination, serological tests, and bacteriology of semen samples (Burgess, 1982). Several serologic methods are employed to detect antibodies against $B$. ovis, including agar gel immunodiffusion (AGID), complement fixation (CF), and enzyme linked immunosorbent assay (ELISA) (Marín et al., 1989). However, serological diagnosis is not entirely satisfactory

Recebido em 20 de setembro de 2010

Aceito em 6 de março de 2012

*Autor para correspondência (corresponding author)

E-mail: rsantos@vet.ufmg.br since it commonly provides highly variable results, with high frequency of false-negative (Nozaki et al., 2004). Although bacteriology is considered the gold standard for diagnosis, it is laborious, time consuming, and its results may be compromised by environmental contamination (Manterola et al., 2003). Molecular techniques based on amplification of Brucella spp. genomic DNA have been applied to the diagnosis of $B$. ovis infections (Manterola et al., 2003; Saunders et al., 2007). Our group has recently developed a species-specific PCR assay for detection of $B$. ovis genomic DNA in biological samples, including semen, preputial wash, and urine (Xavier et al., 2010). This study aimed to evaluate the applicability of a species-specific PCR method under field conditions, using urine samples to detect B. ovis by PCR and to compare to serology (AGID).

Serum and urine samples were collected from 90 rams belonging to 31 herds located in the State of Piauí. Blood samples were collected with vacuntainer tubes without EDTA (BD - Becton, Dickinson Co., USA) from the jugular vein, and then centrifuged. Serum samples were aliquoted in cryogenic tubes. Urine samples were collected by blocking breathing for 30 seconds and aliquoted in cryogenic tubes. Serum and urine were stored in liquid nitrogen.

Serum samples were tested by the AGID method as previously described by Marín et al. (1989). The used antigen was produced from soluble extract of heat-inactivated strain of $B$. ovis strain REO 198 by Instituto de Pesquisas Desidério Finamor, Rio Grande do Sul, Brazil. 
DNA extraction from urine samples was performed with $1 \mathrm{~mL}$ of urine according to the protocol previously described by Xavier et al. (2010). Two pairs of primers of a specific genetic island of $B$. ovis, determining the specific amplification of $B$. ovis, were used in this study (Tsolis et al., 2009). The primers were designed to target a specific B. ovis open reading frame, namely AO503 (Tsolis et al., 2009): 5'GCCTACGCTGAAACTTGCTTTTG-3' and 5'ATCCCCCCATCACCATAACCGAAG-3'. PCR reaction was performed using $23 \mu \mathrm{L}$ of commercial PCR Supermix (Invitrogen, Brazil), $0.5 \mu \mathrm{L}$ of each primer at $25 \mu \mathrm{M}, 0.25 \mu \mathrm{L}$ of Taq polymerase (Invitrogen, Brazil), and $3 \mu \mathrm{L}$ of template DNA (100-500ng of DNA per reaction). Cycling parameters consisted of denaturation at $95^{\circ} \mathrm{C}$ for 5 minutes, 35 cycles of denaturation $\left(95^{\circ} \mathrm{C}\right.$ for 1 minute), annealing $\left(55^{\circ} \mathrm{C}\right.$ for 1 minute), extension $\left(72^{\circ} \mathrm{C}\right.$ for 1 minute) and a final extension at $72^{\circ} \mathrm{C}$ for 5 minutes. PCR products were resolved by $1 \%$ agarose gel eletrophoresis. Specific PCR products had 228 base pairs.

Frequencies of positivity by AGID and PCR were compared by the Fisher's exact test using GraphPad Instat software, version 3.05 (GraphPad Instat, Inc., U.S.A.). Agreement between these two methods was evaluated by the Kappa test using Minitab 15 software (Global Tech, Brazil).

Eighteen out of 90 urine samples analyzed (20\%) were positive by PCR, while 16 (17.8\%) serum samples were positive by AGID. Four out of 31 farms assessed had positive rams by PCR, AGID, or both tests corresponding to $12.9 \%$ of positive herds. There was no statistical difference between methods considering the frequency of positive rams $(\mathrm{P}>0.05)$. However, kappa statistics indicated a low concordance between these methods $(\mathrm{k}=0.02)$. In spite of this low level of agreement between serology and PCR, combination of these methods resulted in a significantly increase frequency of positive diagnosis when compared to any of the methods individually $(\mathrm{P}<0.05)$, resulting in identification of $34.4 \%$ of positive rams.

These results clearly indicates that neither PCR nor serology are completely reliable diagnostic methods for individual rams since serologically negative rams can excrete the organism whereas serologically positive rams may not excrete the organism. Previous studies from our group have demonstrated that this species-specific PCR method has levels of sensitivity comparable or superior to bacterial isolation (Xavier et al., 2010). Furthermore, there is no good agreement between serology and PCR results even during the course of experimental infections (Xavier et al., 2010). The high occurrence of asymptomatic infections by $B$. ovis makes it very difficult to establish a clinical diagnosis. According to Burgess (1982), shedding of B. ovis in the semen is considered the main source of infection in the herd. Therefore, semen is considered the sample of choice for detection of $B$. ovis (Manterola $e t$ al., 2003, Saunders et al., 2007). However, B. ovis elimination in semen is intermittent, which can impair diagnostic sensitivity (Manterola et al., 2003, Saunders et al., 2007). In addition, considering that semen collection under field conditions is quite laborious, urine samples have been tested and proved to result in similar levels of sensitivity as compared to semen samples from experimentally infected rams (Xavier et al., 2010).

It is noteworthy that sheep is also susceptible to $B$. melitensis infection, and that in sharp contrast to $B$. ovis (that does not infect humans), $B$. melitensis is the species within the Brucella genus with the highest zoonotic potential (Xavier et al., 2009). Therefore, the species-specific PCR method employed in this study is highly desirable since it allows a differential diagnosis in areas where $B$. melitensis is enzootic, favoring epidemiological investigations and implementation of an appropriate control program.

In conclusion, in spite of a low agreement between serology and PCR, the species-specific PCR method employed in this study demonstrated to be a suitable complementary diagnostic method for identification of $B$. ovis infected rams. Furthermore, this method allows identification of serologically negative rams shedding the organism in the environment. These results support the notion that PCR of urine samples can be considered an important tool for the diagnosis of natural infections by $B$. ovis.

Keywords: Brucella ovis, sheep, diagnosis, PCR, AGID 


\section{RESUMO}

A brucelose ovina causada pela Brucella ovis é uma doença reprodutiva de carneiros caracterizada por epididimite, orquite, com consequente diminuição da fertilidade e prejuízos econômicos significativos. $O$ presente trabalho teve por objetivo avaliar a aplicabilidade da técnica de PCR como um método de diagnóstico em campo, comparado-a com a técnica de IDGA. Foram coletadas amostras de urina e soro de 90 carneiros oriundos de 31 rebanhos localizados no Estado do Piauí. Quatro das 31 (12,9\%) propriedades avaliadas apresentaram animais positivos. Dezoito (20\%) amostras de urina foram positivas pela PCR, enquanto o método de IDGA identificou $16(17,8 \%)$ carneiros soropositivos. Embora os métodos tenham apresentado concordância baixa na estatística Kappa $(k=0,04)$, não foi observada diferença estatística entre as técnicas $(P>0,05)$ pelo teste exato de Fisher. A combinação dos dois testes aumentou significativamente a detecção de animais positivos para 34,4\% ( $P<0,05)$, sugerindo que a associação de métodos de diagnóstico como a técnica de PCR em amostras de urina e sorologia por IDGA e a avaliação clínica dos animais é necessária para um diagnóstico eficiente na infecção por $B$. ovis.

Palavras-chave: Brucella ovis, ovinos, diagnóstico, PCR, IDGA

\section{ACKNOWLEDGMENTS}

Financial support was provided by Conselho Nacional de Desenvolvimento Científico e Tecnológico (CNPq), Coordenação de Aperfeiçoamento de Pessoal de Nível Superior (CAPES), and Fundação de Amparo à Pesquisa do Estado de Minas Gerais (FAPEMIG). FMS, EAC, VSM, and RLS have fellowships from CNPq. RLS is currently a fellow at the John Simon Guggenheim Memorial Foundation.

\section{REFERENCES}

AZEVEDO, S.S.; ALVES, C.J.; ALVES, F.A.L. et al. Ocorrência de anticorpos anti-Brucella ovis em ovinos procedentes de quatro municípios do Estado do Rio Grande do Norte, Brasil. Agrop. Tec., v.25, p.45-50, 2004.

BURGESS, G.W. Ovine contagious epididimytis: a review. Vet. Microbiol., v.7, p.51-575, 1982.

CLEMENTINO, I.J.; ALVES, C.J.; AZEVEDO, S.S. et al. Inquérito soro-epidemiológico e fatores de risco associados à infecção por Brucella ovis em carneiros deslanados no semiárido da Paraíba. Pesq. Vet. Bras., v.27, p.137143, 2007.

COLETO, Z.F.; PINHEIRO JÚNIOR, J.W.; MOTA, R.A. Ocorrência de infecção por Brucella ovis em ovinos do Estado de e sua participação em distúrbios reprodutivos nesta espécie (estudos preliminares). Rev. Bras. Reprod. Anim., v.27, p.551-553, 2003.
MAGALHÃES NETO, A.; GIL-TURNES, C. Brucelose ovina no Rio Grande do Sul. Pesq. Vet. Bras., v.16, p.75-79, 1996.

MANTEROLA, L.; TEJERO-GARCES, A.; FICAPAL, A. et al. Evaluation of a PCR test for the diagnosis of Brucella ovis infection in semen samples from rams. Vet. Microbiol., v.92, p.6572, 2003 .

MARÍN, C.M.; JIMENES DE BAGUES, M.P.; BLASCO, J.M. et al. Comparison of three serological tests for Brucella ovis infection of rams using different antigenic extracts. Vet. Rec., v.125, p.504-508, 1989.

NOZAKI, C.N.; MEGID, K.C.; SILVA JUNIOR, F.F.; VELOSO, C.S. Comparação das técnicas de imunodifusão em gel de ágar e ELISA no diagnóstico de brucelose ovina em cabanhas da região Centro-Oeste do Estado de São Paulo. Arq. Inst. Biol., v.71, p.1-5, 2004.

ROBLES, C.A.; LA TORRACA, A.; SANCHOLUZ, M. et al. Brucelosis ovina en majadas merino de la provincia de Chubut, Argentina. Vet. Argent., v.10, p.458-461, 1993.

SAUNDERS, V.F.; REDDACLIFF, L.A.; BERG, T. et al. Multiplex PCR for the detection of Brucella ovis, Actinobacillus seminis and Histophilus somni in ram semen. Aust. Vet. J., v.85, p.72-77, 2007.

SERGEANT, E.S.G. Seroprevalence of Brucella ovis infection in commercial ram flocks in the Tamworth area. N. Z. Vet. J., v.42, p.97-100, 1994. 


\section{Costa et al.}

TSOLIS, R.M.; SECHADRI, R.; SANTOS, R.L. et al. Genome degradation in Brucella ovis corresponds with narrowing of its host range and tissue tropism. PLoS One, v.4, p.1-9, 2009.

XAVIER, M.N.; COSTA, E.A.; PAIXÃO, T.A. et al. The genus Brucella and clinical manifestations of brucellosis. Cienc. Rural, v.39, p.2252-2260, 2009.
XAVIER, M.N.; SILVA, T.M.A.; COSTA,

E.A.C. et al. Development and evaluation of a species-specific PCR assay for the detection of Brucella ovis infection in rams. Vet. Microbiol., v.145, p.158-164, 2010. 